\title{
AKUNTANSI SEKTOR PUBLIK PERENCANAAN DAN PENGELOAAN DANA YAYASAN WIDYA ASIH
}

\author{
I Wayan Yasa Adi Upadana, Dipa Sanjaya, Krisna Nawasta Nugraha, \\ Ngurah Bagus Sony Aditya, Agus Ari Wiratama \\ Jurusan Akuntansi, Universitas Pendidikan Ganesh, Singaraja, Bali, Indonesia
}

\begin{abstract}
Abstrak
Penelitian ini bertujuan untuk mengetahui bagaimana ruang lingkup Yayasan, bagaimana akuntabilitas sebuah yayasan, bagaimana proses penyusunan anggaran yayasan Widhya Asih, bagaimana pengelolaan dana dalam yayasan, apa dampak yang ditimbulkan apabila terdapat penyimpangan dana pada yayasan. Dari hasil penelitian Yayasan widhya asih merupakan yayasan yang menampung anak - anak tidak memiliki orang tua dari yatim, piatu, maupun yatim piatu dan juga menampung anak dari keluarga yang kurang mampu ( dititipkan ). Penyusunan anggaran yang dilakukan oleh pihak yayasan menyesuaikan dengan kebutuhan dari anak - anak di yayasan itu sendiri. Walaupun sedikit dana yang diperoleh, namun pihak yayasan memiliki cara untuk mengolah sesuatu menjadi barang yang memiliki nilai jual dan dari hasil kreativitas anak - anak di dalam yayasan tersebut.
\end{abstract}

Kata kunci: Perencanaan, Pengelolaan, Dana

\begin{abstract}
Penelitian ini bertujuan untuk mengetahui bagaimana ruang lingkup Yayasan, bagaimana akuntabilitas sebuah yayasan, bagaimana proses penyusunan anggaran yayasan Widhya Asih, bagaimana pengelolaan dana dalam yayasan, apa dampak yang ditimbulkan apabila terdapat penyimpangan dana pada yayasan. Dari hasil penelitian Yayasan widhya asih merupakan yayasan yang menampung anak - anak tidak memiliki orang tua dari yatim, piatu, maupun yatim piatu dan juga menampung anak dari keluarga yang kurang mampu ( dititipkan ). Penyusunan anggaran yang dilakukan oleh pihak yayasan menyesuaikan dengan kebutuhan dari anak - anak di yayasan itu sendiri. Walaupun sedikit dana yang diperoleh, namun pihak yayasan memiliki cara untuk mengolah sesuatu menjadi barang yang memiliki nilai jual dan dari hasil kreativitas anak - anak di dalam yayasan tersebut.
\end{abstract}

Keywords : Perencanaan, Pengelolaan, Dana

\section{Pendahuluan}

Yayasan adalah kumpulan dari sejumlah orang yang terorganisasi dan dilihat dari segi kegiatannya, lebih tampak sebagai lembaga sosial. Sejak awal sebuah yayasan didirikan bukan untuk tujuan komersial atau untuk mencari keuntungan, akan tetapi tujuannya didirikan yayasan adalah untuk membantu dan meningkatkan kesejahteraan orang lain.Yayasan, dalam bahasa Belanda disebut Stichting, dalam KUH Perdatayang berlaku di Indonesia tidak terdapat pengaturannya. Istilah yayasan dapatdijumpai dalam beberapa ketentuan KUH Perdata antara lain dalam Pasal 365,Pasal 899, Pasal 900 dan Pasal 1680

Anggaran merupakan elemen penting dalam sistem pengendalian manajemen, karena anggaran adalah sebagai alat perencanaan (planing), dan pengendalian (control) jangka pendek yang efektif dalam organisasi (Anthony \& Govindarajah 2005).Dalam yayasan sendiri anggaran yang diberikan pemerintah digunakan untuk menjalankan program kerja serta pemeliharaan fasilitas dan oprasional dalam yayasan sehingga anggaran yang diberikan pemerintah haruslah cukup untuk memenuhi hal mengenai hal diatas

Dalam pemberian anggaran pemerintah seringkali mengurangi dana yang diajukan yayasan dikarenakan berbagai macam faktor sehingga hal tersebut memengaruhi programprogram yayasan yang sudah direncanakan sebelumnya. Hal ini sangat disayangakan karena yayasan yang akan menanggung kekurangan tersebut yang berakibat pada tidak 
maksimalnya kinerja yayasan terhadap program kerja yang akan dijalankan dan telah direncanakan sebelumnya

Hal ini terjadi pada yayasan Widhya Asih yang berada di jalan WR. Supratman,Gang Undis, Penarukan,Singaraja, Kabupaten Buleleng, Bali. Dimana anggaran yang diberikan pemerintah belum mencukupi atau kurang yang seharusnya digunakan untuk menjalankan program kerja dan perawatan fasilitas namun harus biayai oleh yayasan dengandana seadanya bahkan harus ditunda dan tidak bisa dijalankan sama sekali

Berdasarkan permasalahan diatas, adapun rumusan masalah yang dilakuakan yaitu bagaimana ruang lingkup Yayasan, bagaimana akuntabilitas sebuah yayasan, bagaimana proses penyusunan anggaran yayasan Widhya Asih, bagaimana pengelolaan dana dalam yayasan, apa dampak yang ditimbulkan apabila terdapat penyimpangan dana pada yayasan.

\section{Hasil dan Pembahasan Pengertian Dan Ruanglingkup Yayasan}

Menurut UU No. 16 Tahun 2001, sebagai dasar hukum positif Yayasan, pengertian yayasan adalah badan hukum yang kekayaannya terdiri dari kekayaan yang dipisahkandan diperuntukan untuk mencapai tujuan tertentu dibidang social, keagamaan, dan kemanusiaan.

Yayasan berbeda dengan perkumpulan karena perkumpulan memiliki pengertian yang lebih luas, yaitu meliputi suatu persekutuan, koperasi, dan perkumpulan saling menanggung.

Di pihak lain, yayasan merupakan bagian dari perkumpulan yang berbentuk Badan Hukum dengan pengertian yang dinyatakan dalam Pasal 1 butir 1 UU No. 16 Tahun 2001 tentang yayasan, yaitu suatui Badan Hukum yang kekayaannya terdiri dari kekayaan yang dipisahkan untuk mencapai tujuan tertentu di bidnang social, keagamaan, dan kemanusiaan dengan tidak mempunyai anggota.

Yayasan sebagai suatu badan hukum mampu dan berhak serta berwenang untuk melakukan tindakan-tindakan perdata. Pada dasarnya, keberadaan badan hukum yayasan bersifat permanen. Yaitu hanya dapat dibubarkan melalui persetujuan para pendiri dan anggotanya. Yayasan hanya dapat dibubarkan jika segala kietentuan dan persyaratan dalam anggaran dasarnya telah dipenuhi.

\section{a. Sifat Dan Karakteristik Yayasan}

b. Tujuan Yayasan

Setiap organisasi, termasuk yayasan, memiliki tujuan yang spesifik dan unik yang dapat bersifat kuantitatif maupun kualitatif. Tujuan yang bersifat kuantitatif mencakup pencapaian laba maksimum, penguasaan pangsa pasar, pertumbuhan organisasi, dan produktivitas. Sementara tujuan kualitatif dapat di sebutkan sebagai efisiensi dan efektivitas organisasi, manajemen organisasi yang tangguh, moral karyawan yang tinggi, reputasi organisasi, stabilitas, pelayanan kepada masyarakat, dan citra perusahaan. Sumber Pembiayaan/kekayaan Sumber pembiayaan yayasan berasal dari sejumlah kekayaan yang dipisahkan dalam bentuk uang atau barang. Selain itu, yayasan juga memperoleh sumbangan atau bantuan yang tidak mengikat, seperti berupa;

1. Wakaf;

2. Hibah;

3. Hibah wasiat;

4. Perolehan lain yang tidak bertentangan dengan Anggaran Dasar Yayasan dan peraturan perundang-undangan yang berlaku.

5. Pola Pertanggungjawaban

Dalam yayasan, pengelola bertanggung jawab pada kepada Pembina yang disampaikan dalam Rapat Pembina yang diadakan setahun sekali. Pola pertanggung jawaban diyayasan bersifat vertical dan horizontal. Pertanggung jawaban vertical adalah pertanggung jawaban atas pengelolaan dana pada otoritas yang lebih tinggi, seperti pertanggung jawaban yayasan kepadaPembina. Sedangkan pertanggung jawabah horizontal adalah pertanggung jawaban ke masyrakat luas. Kedua jenis pertanggung jawaban sector public tersebut mmerupakan elemen penting dari proses akuntabilitas public. 
Pertanggungjawaban manajemen merupakan bagian terpenting bagi kredibilitas manajemen di yayasan. Tidak terpenuhinya prinsip pertanggungjawaban tersebut dapat menimbulkan implikasi yang luas.

a. Struktur Organisasi Yayasan

Struktur organisasi yayasan merupakan turunan dari fungsi, strategi, dan tujuan organisasi. Sementara itu, tipologi pemimpin, termasuk pilihan dan orientasi organisasi, sangat berpengaruh terhadap pilihan struktur birokrasi pada yayasan. Menurut Undangundang No. 16 Tahun 2001, yayasan mempunyai organ yang terdiri dari Pembina, pengurus, dan pengawas. Pembina adalah organ yayasan yang mempunyai kewenangan yang tidak di serahkan kepada pengurus atau pengawas oleh Undangundang tersebut atau Anggaran Dasar. Pengurus adalah organ yayasan yang melaksanakan kepengurusan yayasan, dan pihak yang dapat diangkat menjadi pengurus adalah individu yang mampu melakukan perbuatan

hukum. Sedangkan Pengawas adalah organ yayasan yang bertugas melakukan pengawasan serta member nasihat kepada pengurus dalam menjalankan yayasan.

b. Karakteristik Anggaran

Berdasarkan karakteristik anggaran, rencana anggaran yayasan dipublikasikan kepada masyarakat secara terbuka untuk dkritisi dan di diskusikan. Anggaran tidak boleh menjadi rahasia internal yayasan yang bersangkutan dan harus di informasikan kepada public untuk di kritik, didiskusikan, dan diberi masukan. Anggaran merupakan instrumen akuntabilitas atas pengelolaan dana public dan pelaksanaan programprogram yang dibiayai dengan uang public.

c. System Akuntansi

Sistem akuntansi merupakan prinsip akuntansi yang menentukan kapan transaksi keuangan harus diakui untuk tujuan laporan keuangan. System akuntansi ini berhubungan dengan waktu/kapan pengukuran dilakuakan, dan pada umumnya, bisa dipilih menjadi system akuntansi berbasis kas dan berbasis akrual. Selain kedua system akuntansi tersebut, banyak variasi atau modifikasi dari keduanya, yaitu modifikasi dari akuntansi berbasis kas dan modifikasi dari akuntansi berbasis akrual.

Pada sebuah yayasan, penekanan di berikan pada penyediaan biaya data yang disajikan dalam bentuk laporan keuangan yang menggunakan sisitem akuntansi berbasis akrual - yaitu akuntansi pendapatan biaya.

\section{Perencanaan Yayasan}

Perbedaan utama antara rennca trategis dan rencana jangka pajang adalah focus pengembangan. Pada umumnya perencanaan jangka panjang dipertimbangkan dalam rencana tindakan untuk suatu tujuan atau serangkaian selama beberapa tahun. Asumsi utama rencana jangka panjang adalah terpenuhinya informasi tentang kondisi masa depan. Sebagai contoh, dalam lima puluh tahun terakhir dan enam puluh pertama ekonomi amerika secara relative stabil dan oleh karena itu, dapat diprediksi. Perencanaan jangka panjang sangat banyak modelnya, dan semua dilandasi oleh lingkungan asusi yang tidak dapat diprediksi. Focus perencanaan adalah penyelesaian tujuan yang telah disepakati

Yayasaan sebagai suatu organisasi non profit, mengarahkanproses perencanaan dan sumber daya yang tersesia untuk memaksimalkan manfaat yang akan diperoleh . sumber daya utama yang diperlukan untuk perencanaan adalah waktu pengelola, waktu Pembina, dan uang

\section{Investasi Yayasan}

Dlam meaksanakan fungsi pelayanan masyarakat, yayasan dihadapkan pada masalah pengambilan keputusan investasi yang diperlukan untuk mendukung pelaksanaan program, kegiatan, dan fungsi yang menjadi prioritas kebijakan. Pengeluaran untuk investasi harus mendapat perhatian yang lebih besar dibandingkan dengan pengeluaran rutin, karena pengeluaran investasmodal memiliki dampak jangka panjang, sedangkan pengeluaran rutin lebih berdampak jangka pendek. Kesalahan dalam mengambil keputusan investasi tidak saja akan berdampak terhadap anggaran tahun berjalan, tetapi juga akn membebani anggaran tahun-tahun berikutnya. 
Investasi memiliki kaitan erat dengan penggunaan modal/investasi. Penganggaran modal investasi merupakan proses untuk menganalisis proyek-proyek dan meemutuskan apakah proyek tersebut dapat dapat diakomodasi oleh anggaran modal/investasi. Untuk memberikan mekanisme dalam mengatur proyek investasi secara lebih efisien dan efektif , perlu dilakukan analisis investasi secara mendalam. Analisis investasi berhubungan erat dengan penganggaran fungsional,alokasi sumber daya, dan praktek manajemen keuangan di sector pubik. Selain itu program investasi juga merupakan bentuk dari dual budgeting, yitu pemisahan anggaran modal/investasi dari anggaran rutin

\section{Akuntabilitas Yayasan}

1. Tujuan Laporan Keuangan

Tujuan utama laporan keuangan adalah menyediakan informasi yang relevan untuk memenuhi kepentingan para penyumbang, anggota pengelola, kreditor, dan pihak lain yang menyediakan sumber daya bagi yayasan. Pihak pemakai laporan keuangan yayasan memiliki kepentingan bersama dalam rangka menilai:

a. Jasa yang diberikan oleh yayasan dan kemampuannya untuk terus memberikan jasa tersebut.

b. Cara pengelola melaksanakan tanggung jawabnya dan aspek lain dari kinerja yayasan.

Setiap laporan keuangan menyediakan informasi yang berbeda, dan informasi dalam suatu laporan keuangan biasanya melengkapi informasi laporan keuangan lain. Secara rinci tujuan laporan keuangan termasuk catatan atas laporan keuangan, adalah untuk menyajikan informasi mengenai:

1. Jumlah dan aktiva, kewajiban serta aktiva bersih suatu yayasan

2. Pengaruh transaksi, peristiwa, dan situasi lainnya yang mengubah nilai serta sifat aktiva bersih

3. Jenis dan jumlah arus masuk serta arus keluar sumber daya selama satu periode dan hubungan diantara keduanya

4. Cara suatu yayasan mendapatkan dan membelanjakan kas, memperoleh pinjaman dan melunasi pinjama, serta faktor lainnya yang berpengaruh terhadap likuiditasnya Usaha jasa suatu yayasan.

2. Unsur-unsur dalam Sistem Akuntansi

Sistem akuntansi terdiri dari catatan-catatan akuntansi (buku cek, jurnal, dan buku besar), serta serangkaian proses dan prosedur yang ditetapkan untuk staf, sukarelawan, dan/atau para profesional dari luar yayasan. Secara tradisional akuntansi terdiri dari komponen- komponen berikut ini :
a. Bagan Perkiraan/Akun
b. Buku Besar
c. Jurnal
d. Buku Cek
e. Manual prosedur akuntansi
f. Siklus akuntansi.

3. Mempertahankan Integritas Sistem Akuntansi a. Neraca saldo (Trial Balance)

Dalam sistem manual, seluruh saldo buku besar dihitung atas basis bulanan untuk memastikan bahwa total debet sama dengan total kredit. Apabila debet sama dengan kredit, laporan keuangan dapat disajikan dengan menggunakan jumlah neraca saldo. Sistem akuntansi yang terkomputerisasi akan menghasilkan neraca saldo dengan mekanisme bilt-in.

Tahap Pengembangan Sistem Akuntansi

Sistem akuntansi yang di terapkan akan berubah sebagaimana halnya dengan sumber daya dan kebudayaan yayasan. Yayasan bersekala kecil yang baru berdiri hanya perlu mempertahankan akurasi catatan aktivitas dalam buku cek. Dengan kompleksitas dan volume kerja yayasan yang semakin berkembang, aktivitas manajemen keuangan membutuhkan peningkatan jumlah staf sukarelawan atau staf yang dibayar atau kombinasi staf dan penyedia jasa dari luar. Jadi, sistem akuntansi harus dirancang sesuai dengan kebutuhan dan kompetensi pemakainya.

4. Perbedaan antara akuntansi untuk yayasan dan organisasi bisnis 
Prinsip akuntansi yang diterima umum bisa diterapkan dalam praktek akuntansi nonprofit. Namun, ada beberapa perbedaan yang signifikan sebagai berikut.

a. Akuntansi untuk sumbangan

Yayasan yang memenuhi syarat untuk mendapatkan status bebas pajak akan ditunjuk untuk menerima sumbangan. Prosedur yang ekuivalen untuk menangani akuntansi sumbangan dalam yayasan adalah prosedur khusus, yaitu:

- Janji atau komitmen (jaminan untuk memberikan)

- Jasa dan materi yang didermakan (jenis sumbangan)

- Kejadian-kejadian khusus Hak Keanggotaan Pembina

b. Kapitalisasi dan penyusutan aktiva

Yayasan perlu mencatat pembelian barang dan peraltan substansial jangka panjang seperti komputer, mobil, dan bangunan, sebagai aktiva serta menanggung porsi biaya per tahun untuk barang- barang yang masih memiliki umur manfaat. Proses ini disebut sebagai kapitalisasi dan penyusutan aktiva tetap. Yayasan juga perlu mencatat penyusutan aktiva. Namun ada beberapa aktiva di sektor nonprofit yang menerima prlakuan khusus seperti koleksi museum, bangunan sejarah, buku perpustakaan, dan kebun binatang.

c. Klasifikasi pengeluaran fungsional

Yayasan perlu melaporkan pengeluaran kas sesuai dengan klasifikasi fungsinya. Dua klasifikasi pengeluaran fungsi primer adalah pelayanan program dan aktivitas pendukung. Sementara itu, klasifikasi aktivitas pendukung meliputi pengelolaan dan aktivitas umum, penggalian dana, dan pengembangan keanggotaan. Praktek tersebut sangat bervariasi dari satu yayasan ke yayasan lainnya.

d. Implikasi perbedaan antara akuntansi nonprofit dan akuntansi swasta Implikasi dari perbedaan praktek akuntansi non profit dan akuntansi swasta adalah diperlukannya keahlian tambahan bagi personil, penasihat keuangan, atau auditor. Jadi, sumbangan dan pambelian barang-barang serta peralatan yang memerlukan penanganan khusus, diatur dengan melibatkan seorang akuntan spesialis yayasan.

5. Perbedaan Akuntansi Berbasis Kas dan Berbasis Akural

Akuntansi berbasis kas dan akuntansi berbasis akural menggunakan kriteria yang berbeda untuk menentukan kapan mengakui serta mencatat pengeluaran dan penerimaan dalam catatan keuangan. Pada akuntansi berbasis kas, pendapatan diakui ketika kas diterima dan disetorkan, sementara biaya dicatat dalam periode akuntansi ketika tagihan dibayarkan. Dalam akuntansi berbasis akrual, pendapatan diwujudkan dalam periode akuntansi ketika pendapatan itu di peroleh, misalnya,saat jasa yang dikontrak diberikan dan ditentukan hibah terpenuhi,tanpa menghiraukan waktu penerimaan kas dari donasi. Belanja dicatat sebagai pengurangan utang saat pembayaran, misal ketika membayar persediaan yang dipesan, membayar lembur karyawan, dan meminjam printer untuk pencetakan.

Contoh transaksi: Yayasan Kemanusiaan Ibu Pertiwi belum membayar cicilan akhir atas pembelian printer secara kredit pada tahun ini, sehingga berhutang Rp 1.500.000. Maka pencatatan jurnal atas transaksi tersebut adalah:

\begin{tabular}{|c|c|c|c|}
\hline \multicolumn{2}{|c|}{ Basis Kas } & \multicolumn{2}{|c|}{ Basis Akrual } \\
\hline $\begin{array}{l}\text { Tidak ad } \\
\text { membayar }\end{array}$ & jurnal belum & $\begin{array}{l}\text { Peralatan } \\
\text { Utang Usaha }\end{array}$ & $\begin{array}{l}1.500 .000 \\
1.500 .000\end{array}$ \\
\hline Peralatan & 1.500 .000 & Utang Usaha & 1.500 .000 \\
\hline Kas & 1.500 .000 & Kas & 1.500 .000 \\
\hline
\end{tabular}


Beberapa yayasan tidak memiliki sumber daya untuk mengembangkan sistem akuntansi yayasan. Faktor-faktor pertimbangan basis akuntansi adalah:

1. Besaran transaksi yayasan dalam piutang dan pembayaran atas basis yang terusmenerus. Jika tagihan atau hibah belum dibayar atau dilunasi sepanjang tahun, maka akuntansi berbasis kas akan memberikan gambaran keuangan yang sama baiknya dengan akuntansi berbasis akrual.

2. Keahlian dan waktu yang membatasi staf pembukuan.

3. Posisi arus kas yayasan. Jika arus kas dijadikan fokus, maka akun pembayaran dan piutang dapat dijadikan pengendali.

4. Ukuran anggaran yayasan. Beberapa yayasan yang baru belum memiliki kewajiban pembayaran dan tidak memiliki piutang akan memilih akuntansi berbasis kas.

5. Bagan Akun

a. Unsur-unsur yang Harus Ada dalam Bagan Akun

Bagan akun merupakan daftar prakiraan (rekening) sistem akuntansi yang dirancang untuk mendapatkan informasi keuangan, mempertahankan jalur informasi keuangan, dan membuat keputusan keuangan. Informasi tersebut hanya dicatat dengan kode akun dari bagan akun.

Cara terbaik untuk merancang bagan akun atau perkiraan adalah dengan mempertimbangkan laporan apa yang diperlukan untuk memenuhi persyaratan eksternal, pengambilan keputusan, dan penilaian pengelola. Sebagai contoh, bagan akun harus berhubungan dengan kategori anggaran, sehingga laporan yang dihasilkan dapat membandingkan apa yang dianggarkan dengan realisasinya.

Aturan yang baik adalah membuat bagan akun sesederhana mungkin dan memperbaikinya untuk meningkatkan ketersediaan informasi secara berkesinambungan. Hal yang dituliskan dalam cek atau penerimaan uang adalah nomor akun yang ditetapkan untuk untuk transaksi. Hal ini dapat menjadi indikator bahwa bagan akun perlu direvisi. Dengan kata lain, kriteria penentuan nomor akun dijelaskan.

b. Ciri-ciri Bagan Akun yang Sederhana

Bagan akun yang diberikan pada akhir bagian ini menggambarkan kesesuaian item belanja dan pendapatan dengan nomor akun yang berlaku. Contoh dibawah ini merupakan pedoman tentang pengembangan bagan akun itu sendiri. Ciri-ciri dari contoh bagan akun berikut perlu diamati dengan seksama. Kategori akun disajikan dalam urutan standar dimulai dengan akun yang disajikan dalam Laporan Posisi Keuangan sebagai berikut:

1. Aktiva

Aktiva adalah item nyata dari suatu yayasan dimana sumber daya, termasuk kas, akun piutang, perlengkapan, dan kekayaan, diungkapkan. Aktiva biasanya dimasukkan dalam daftar menurut urutan menurun (descending) dari likuiditasnya. Hal ini berarti bahwa kas dan aktiva lainnya yang mudah diubah menjadi kas dicantumkan pada urutan awal; dan aktiva tetap seperti kekayaan dan peralatan diurutan akhir. Akun aktiva biasanya dimulai dengan angka "1".

2. Utang

Utang adalah kewajiban ke kreditor seperti pinjaman dan utang usaha. Utang yang jatuh temponya sekarang dicantumkan lebih awal dibanding utang yang jatuh temponya dalam tahun berikutnya. Utang usaha dan utang pajak upah biasanya dicantumkan sebelum utang lainnya. Penerimaan yang ditangguhkan dan utang lainnya sering kali dicantumkan dalam urutan berikutnya pada daftar. Utang sering kali dimulai dengan angka "2".

3. Aktiva Bersih

Aktiva bersih mencantumkan nilai keuangan dari suatu yayasan. Aktiva tersebut mencerminkan saldo yang ada setelah kewajiban yayasan dilunasi. Perangkat lunak akuntansi yang dirancang untuk yayasan melaporkan "aktiva bersih". Sementara itu, yayasan penerima pemberian yang tidak terikat memiliki satu akun aktiva bersih. Aktiva tetap yang terikat, baik secara permanen maupun 
temporer, seperti sumbangan memiliki lebih dari satu akun aktiva bersih, yang biasanya dimulai dengan angka " 3 ".

c. Menangkap Informasi Keuangan yang Lebih Kompleks

Jika dana secara terpisah (dana terikat secara permanen maupun temporer) dipilah menurut setiap program, departemen, dan tempat, maka bagan akun dirancang untuk mengakomodasi kebutuhan tersebut dengan bagan akun "multi-tiered" (deretan bertingkat banyak). Sebagai contoh, dalam bagan akun yang memperlihatkan deretan bertingkat tunggal, penambahan bagian atau deretan bertingkat yang kedua untuk kode akun akan memberikan kode dari berbagai item kedalam berbagai kategori. Misalkan suatu yayasan memiliki tiga program yaitu: konseling, tutorial, dan rekreasi. Setiap program itu mempunyai kode akun sendiri seperti:

1. Konseling

2. Tutorial

3. Rekreasi

Bagan akun akan menjadi lebih kompleks jika yayasan menginginkan laporan yang lebih rinci. Namun, sekali lagi, hal itu tergantung pada waktu dan kemampuan staf keuangan serta kerumitan transaksi keuangan.

Yayasan harus mencatat pembelian peralatan dan kekayaan yang bersifat jangka panjang, karena jenis aktiva tersebut menanggung biaya per tahun sesuai dengan umur manfaatnya. Proses ini disebut sebagai kapitalisasi dan penyusutan aktiva tetap. Pencatatan akuntansi untuk mencatat penyusutan aktiva tetap yang dimiliki oleh yayasan sama dengan pencatatan akuntansi untuk penyusutan aktiva tetap pada umumnya.

d. Pajak Pengghasilan dari Usaha yang Tidak Terkait

Pendapatan usaha yang tidak terkait adalah pendapatan yang dihasilkan dari suatu perdagangan atau aktivitas usaha yang tidak terkait secara substansial dengan tujuan yayasan. Aktivitas usaha atu aktivitas perdagangan adalah aktivitas yang dilakukan untuk meraih pendapatan melalui aktivitas penjualan barang dagangan atau jasa. Misalnya, toko buku universitas melakukan aktivitas usaha dengan menjual buku textbook ke para mahasiswa dan masyarakat umum.

e. Mencatat Akun Sumbangan

Komitmen untuk memberikan kontribusi secara tertulis bisa dijadikan dasar untuk pencatatan transaksi utang sumbangan. Sebagai contoh, seorang donatur berjanji secara tertulis akan memberikan sumbangan senila $\mathrm{Rp} 1.000 .000$,- selama tiga tahun mendatang. Dengan menyajikan piutang hibah dalam neraca, yayasan memperlihatkan jumlah uang yang diharapkan akan diterima di masa mendatang dalam bentuk sumbangan hibah.

Piutang hibah yang bisa dipercaya sebaiknya dicatat dalam sistem akuntansi. Terdapat dua jenis piutang, yaitu piutang yang mengikat dan piutang yang tidak mengikat. Pituang yang tidak mengikat adalah piutang yang dilakukan oleh donatur untuk memberikan hibah kepada yayasan di masa yang akan datang. Namun yayasan tersebut tidak perlu memenuhi beberapa persyaratan khusus sebelum menerima hibah dan tidak ada kondisi lain yang ditetapkan oleh donatur.

6. Pernyataan Standar Akuntansi Keuangan (PSAK) Di Indonesia a. Laporan Keuangan Organisasi Nonprofit.

Laporan keuangan organisasi nonprofit seperti yayasan meliputi laporan posisi keuangan pada akhir periode pelaporan, laporan aktivitas serta laporan arus kas untuk suatu periode pelaporan, dan catatan atas laporan keuangan.

a. Laporan Posisi Keuangan

1. Klasifikasi aktiva dan kewajiban Informasi mengenai likuiditas diberikan dengan cara sebagai berikut:

2. Menyajikan aktiva berdasarkan urutan likuiditas dan kewajiban berdasarkan tanggal jatuh tempo

3. Mengelompokkan aktiva ke dalam bagian lancer dan tidak lancar, serta 
kewajiban ke dalam bagian jangka pendek dan jangka panjang

4. Mengungkapkan informasi mengenai likuidasi aktiva atau saat jatuh tempo kewajiban termasuk pembatasan penggunaan aktiva pada catatan atas laporan keuangan

b. Klasifikasi Aktiva Bersih Terikat atau Tidak Terikat Laporan posisi keuangan menyajikan jumlah setiap kelompok aktiva bersih berdasarkan ada atau tidaknya pembatasan oleh penyumbang, yaitu terikat secara permanen, terikat secara temporer, dan tidak terikat Informasi mengenai sifat dan jumlah dari pembatasan permanen atau temporer akan diungkapkan dengan cara menyajikan jumlah tersebut dalam laporan keuangan atau catatan atas laporan keuangan

a. Laporan Aktivitas

Tujuan dan Laporan aktivitas difokuskan pada yayasan secara keseluruhan dan menyajikan perubahan jumlah aktiva bersih selama suatu periode. Perubahan aktiva dalam laporan aktivitas akam tercermin pada aktiva bersih dalam laporan posisi keuangan. Pada laporan terdiri atas aktivitas sebagai berikut.

- Perubahan Kelompok Aktiva Bersih Laporan aktivitas menyajikan jumlah perubahan aktiva bersih yang terikat permanen, terikat temporer, dan tidak terikat selama suatu periode.

- Klasifikasi Pendapatan, Beban, Keuntungan, dan Kerugian Laporan aktivitas menyajikan pendapatan sebagai penambah aktiva bersih tidak terikat, kecuali penggunaannya dibatasi oleh penyumbang, dan menyajikan beban sebagai pengurang aktiva bersih tidak terikat

- Informasi Mengenai Pendapatan dan Beban Laporan aktivitas menyajikan jumlah pendapatan dan beban secara bruto, namun demikian, pendapatan investasi dapat disajikan secara netto dengan syarat beban-beban terkait, seperti beban penitipan dan beban penasihat investasi, diungkapkan dalam catatan atas laporan keuangan.

- Informasi Mengenai Pemberian Jasa

Laporan aktivitas atau catatan atas laporan keuangan harus menyajikan informasi mengenai beban menurut klasifikasi fungsional, seperti menurut kelompok program jasa utama dan aktivitas pendukung.

b.Laporan Arus Kas

Tujuan utama laporan arus kas adalah menyajikan informasi mengenai penerimaan dan pengeluaran kas dalam suatu periode. Laporan arus kas disajikan sesuai dengan PSAK 2 tentang laporan arus kas dengan tambahan berikut ini:

1. Aktivitas pembiayaan

2. Pengungkapan informasi mengenai aktivitas investasi dan pendanaan non kas seperti sumbangan berupa bangunan atau aktiva investasi.

\section{Pengendalian Keuangan}

\section{Pengembangan Sistem Pengendalian Akuntansi}

Langkah pertama dalam sistem pengendalian akuntansi yang efektif adalah mengidentifikasi bidang dimana penyalahgunaan atau kesalahan-kesalahan mungkin terjadi. Beberapa akuntan dapat memberikan checklist (daftar pengecekan) atas bidang dan pertanyaan tentang waktu perencanaan sistem. "Price Waterhouse's Booklet, Effective Internal Accounting Control for Nonprofit Organizations: A Guide for Directors and Management", memasukkan bidang dan tujuan pengembangan sistem pengendalian akuntansi yang efektif seperti:

a. Penerimaan Kas

Untuk memastikan bahwa seluruh kas telah diterima, didepositokan secara cepat, dicatat dengan sesuai, direkonsiliasi, dan dipertahankan menurut prosedur keamanan yang memadai.

b. Pengeluaran Kas

Untuk memastikan bahwa semua pembayaran kas hanya dilakukan atas kewenangan pengelola yang tepat, untuk tujuan aktivitas yang valid, dan dicatat secara tepat. 
c. Kas Kecil (petty cash)

Untuk memastikan bahwa kas kecil dan dana kerja lainnya dibayar hanya untuk tujuan yang tepat, disimpan secara aman, dan dicatat secara tepat.

1. Gaji

Untuk memastikan bahwa pembayaran gaji hanya dibuat atas kewenangan yang tepat untuk karyawan yang berhak serta dicatat secara tepat dan berhubungan dengan persyaratan yang sah (seperti setoran pajak gaji).

2. Hibah, Sumbangan, dan Warisan

Untuk memastikan bahwa semua hiba, sumbangan, dan warisan diterima serta dicatat secara tepat dan memenuhi syarat-syarat yang berlaku.

a. Aktiva Tetap

Untuk mamastikan bahwa aktiva tetap diperoleh dan diatur oleh otorisasi yang tepat, dijaga dengan aman, dan dicatat secara tepat.Sistem pengendalian akuntansi juga diperlukan untuk memastikan pencatatan yang tepat atas barang yang didermakan, sumbangan dan penerimaan lainnya. Laporan keuangan dan pengembalian informasi harus dicatat secara akurat dan tepat waktu, dan memenuhi peraturan pemerintah lainnya.

b. Manual Prosedur Akuntansi

Kebijakan dan prosedur untuk menangani transaksi keuangan didokumentasikan dalam Manual Prosedur Akuntansi, dimana tugas- tugas administrasi dan siapa yang bertanggung jawab atas masing- masing tugas tersebut dijelaskan. Manual tersebut merupakan gambaran yang sederhana tentang penanganan fungsi seperti pembayaran tagihan, setoran kas, dan transfer uang. Revisi atas Manual Prosedur Akuntansi biasanya dilakukan untuk mengevaluasi efektivitas pengendalian yang ada.

c. Mempertahankan Pengendalian yang Efektif

Pelaksanan biasanya bertanggung jawab atas pengawasan pelaksanaan kebijakan dan prosedur yang ada. Dengan pensyaratan yang rici dari lembaga donor, sebaiknya harus ada satu orang yang memahami dan memonitor peraturan khusus serta faktor pemenuhannya.Surat manajemen merupakan indikator kualitas pengendalian sistem akuntansi dan bagian dokumen audit yang menyebutkan kelemahan signifikan dari sistem yayasan atau pelaksanaanya. Dengan surat manajemen tersebut pengelola diminta untuk melakukan perubahan sesuai dengan rekomendasi yang diajukan auditor. Denganmembandingkan surat manajemen dari tahun ke tahun, pengelola akan memiliki mekanisme pengawasan tentang penjagaan keuangan dan ketaatan atas kebijakan keuangan.

\section{Pengendalian Internal yang Dibutuhkan untuk Pembayaran Kas}

Tujuan pengendalian internal atas pembayaran kas adalah untuk memastikan ketepatan otorisasi pembayaran kas, keakurasian pencatatan transaksi, dan pencapaian tujuan yayasan. Hal yang perlu dipperhatikan dalam pengendalian internal untuk pembayaran kas adalah pemisahan tugas, otorisasi dan proses pembayaran, pengelolaan dana terbatas, penandatanganan cek, checklist pengendalian akuntansi internal, dan checklist daftar gaji.

\section{Aktivitas Pengendalian Dalam Siklus Akuntansi Tahunan a. Pengelolaan Anggaran Operasional}

Anggaran menggambarkan apa yang diharapkan menyangkut belanja (pengeluaran) dan pendapatan (penerimaan) pada suatu periode waktu. Anggaran tersebut berguna untuk memproyeksikan berapa banyak uang yang dibutuhkan untuk inisiatif utama, seperti pembelian fasilitas dan kontrak karyawan baru. Anggaran operasional juga membantu dalam menjalankan anggaran lainnya, seperti anggarn modal (untuk aktiva utama seperti peralatan, gedung, dII) dan anggaran proposal (untuk penggalian dana). Anggaran tahunan dipersiapkan dengan langkah-langkah sebagai berikut:

1) Pemilihan waktu aktivitas anggaran

Paling tidak dua atau tiga bulan sebelum awal tahun pembukuan, anggaran untuk tahun yang akkan datang sudah mulai dipikirkan. Anggaran tersebut biasanya sesuai dengan tahun pembukuan, yang mencerminkan siklus operasional yayasan. 
2) Pihak yang terlibat dalam proses anggaran

Pengelola harus berpartisipasi di semua tahap proses penganggaran, dimana pertanggungjawaban atas tiap item juga akan dilakukan. Bagi

sebagian besar yayasan, manajemen perencanaan dan keuangan adalah aktivitas yang cenderung memisahkan organisasi.

3) Langkah-langkah dalam proses anggaran

Langkah pertama dalam proses penganggaran adalah mereview program dan pencapaian manajemen serta pelaksanaan keuangan pada akhir tahun. Ini mencakup review atas tujuan yang dicapai, anggaran, dan kinerja perorangan. Selanjutnya, perkiraan biaya yang diperlukan meliputi staff, persediaan, dan sumber daya lain. Pengalaman masa lalu juga dapat menjadi dasar penyusunan anggaran dengan tambahan informasi mengenai kesinambungan program. Penerimaan sumbangan sebaiknya diproyeksikan dengan menggunakan informasi terbaik yang tersedia. Hal itu bukan merupakan angka yang diturunkan dari perbedaan antara biaya yang diproyeksikan dan pendapatan yang diperoleh lainnya serta pengeluaran yang diproyeksikan.

4) Menyiapkan anggaran bulanan

Menyiapkan anggaran bulanan yang mencerminkan pembagian anggaran ke dalam 12 bulan dari penerimaan dan pengeluaran yang ada secara seimbang merupakan hal yang bermanfaat. Dengan menyiapkan rincian anggaran bulanan dan realisasinya, akurasi perubahan dan revisi anggaran dapat dilakukan secara tepat. Anggaran dan proses anggaran dapat menjadi kendaraan yang penting bagi manajemen keuangan dalam mencapai misi secara lebih baik.

5) Menentukan cadangan operasional yayasan

Definisi cadangan operasional atau saldo tidak terikat mirip dengan sisa laba atu kekayaan pemilik. Sisa laba atu kekayaan pemilik adalah dana yang biasanya terakumulasi selama beberapa tahun yang digunakan oleh yayasan sesuai dengan kebijakan pengurus (yaitu penghasilan bersih tidak terikat).

Seluruh pengelola yayasan harus mempelajari perbedaan antara keuntungan dan kas. Keuntungan adalah jumlah uang yang diharapkan bisa diperoleh dari seluruh pelanggan yang membayar tepat pada waktunya. Namun, hal itu bukanlah realitas yang terjadi seharihari. Kas adalah apa yang harus dimiliki untuk mempertahankan pintu usaha tetap terbuka. Bahkan, keuntungan yang diraih yayasan hanya merupakan hal kecil jika tidak disertai dengan arus kas bersih yang positif. Perhatikan bahwa keuntungan tidak dapat dibelanjakan, sementara kas memiliki kemampuan belanja yang riil.

\section{Yayasan Widhya Asih}

Yayasan Widhya Asih merupakan yayasan yang menampung anak yatim, piatu, maupun yatim piatu yang terlantar ataupun yang dititipkan oleh orang tuanya yang kurang mampu. Didirikannya yayasan ini adalah dengan tujuan untuk membantu pemerintah dalam hal mengentas kemiskinan melalui pendidikan. Dibawah naungan GKPB (Gereja Kristen Protestan Di Bali), Widhya Asih Foundation membangun

7 LKSA (namun saat ini hanya ada 6 LKSA) yang berada di Badung, Singaraja, Melaya, Belimbingsari, Bangli dan di Amlapura. Meskipun berada di dibawah naungan gereja, tidak ada penglompokan khusus dalam hal memberikan bantuan kepada masyarakat Bali dalam hal memberikan bantuan pendidikan kepada anak-anak yang keadaan perekonomian keluarganya kurang mampu. Bahkan dalam kenyataannya, kebanyakan anak-anak yang tinggal di LKSA Widhya Asih adalah mayoritas beragama Hindu.

Yayasan ini memiliki visi dan misi yang mulia. Visinya yaitu Widhya Asih sebagai lembaga sosial terdepan yang bekerja untuk mengurangi kemiskinan pada masyarakat di Bali. Misinya Widhya Asih membatu anak - anak yang kurang mampu untuk bisa membantu dirinya sendiri memutuskan roda kemiskinan dengan menyediakan pengasuhan dan perlindungan anak dalam LKSA dan berbasis keluarga, makanan yang bergizi dan kesehatan jasmani - rohani pendidikan formal, pelatihan keterampilan hidup, tempat yang nyaman dan bersih. Yayasan Widhya Asih juga memiliki tujuan yaitu memastikan anak - 
anak yang kurang mampu dapat mengakses hak - hak mereka akan pendidikan dan keamanan yang sesuai dengan hukum yang berlaku Nasional dan Internasional.

Saat ini ada 52 anak yang terdiri dari 4 anak SD, 22 anak SMP, 13 anak SMK, dan 13 anak SMA(berbasis panti asuhan), 14 anak yang dibantu untuk melanjutkan ke Perguruan Tinggi(Berbasis Beasiswa), dan ada beberapa anak yang berbasis keluarga

\section{Pengelolaan Dana Yayasan Widhya Asih}

Yayasan Widhya Asih memanfaatkan dana yang masuk dari pemerintah maupun dari gereja untuk keperluan kebutuhan anak - anak seperti pembelian alat - alat tulis seperti buku, pensil, pulpen, dll.

Selain itu bisa juga digunakan untuk membeli pakaian ataupun tas untuk digunakan ke sekolah. Selain itu juga bisa digunakan untuk pembangunan ataupun perbaikan bangunan yang ada di Yayasan Widhya Asih, seperti perbaikan bangunan yang temboknya sudah lapuk ataupun sudah rusak. Kemudian pembangunan untuk keperluan ruangan tambahan yang akan digunakan untuk pembelajaran ataupun pelatihan - pelatihan yang dilaksanakan oleh yayasan.Berikut adalah lampran anggaran keuanngan Yayasan Widya Asih

\section{Dampak Terjadinya Penyimpangan Dana Pada Yayasan}

Dalam proses penganggaran, akan selalu ada dana yang tidak terealisasikan. Maka hal tersebut dapat menghambat kegiatan operasional yang dilakukan oleh pihak yayasan. Akan banyak kesulian yang akan dirasakan oleh pihak yayasan apabila hal tersebut terjadi. Salah satunya ada hal - hal yang tidak bisa dilaksanakan contohnya apabila ada rencana kegiatan pelatihan di yayasan sedangkan dana yang akan digunakan kurang mencukupi, maka kegiatan tersebut akan ditunda selama satu periode penganggaran kembali. Karena adanya kesulitan yang sering dihadapi, maka pihak yayasan membuat rencana untuk melakukan penggalian dana melalui kegiatan pembuatan batik ataupun kerajinan lain yang bisa dapat dijual dan diterima di masyarakat. Hal tersebut dapat membantu menutupi anggaran yang kurang walaupun mungkin hanya sedikit.

Pihak yayasan hanya mengutamakan kesejahteraan anak - anak di yayasan agar mereka tidak mengalami kesulitan dalam hal ekonomi. Anak - anak panti juga tidak selalu mengeluh apabila ada kegiatan yang tidak terealisasi akibat anggaran yang diperoleh kurang.

Pihak yayasan juga sangat menyayangkan dana yang dianggarkan tidak sesuai dengan dana yang sudah cair, pasalnya pihak yayasan dalam 1 tahun, pihak yayasan bisa menghabiskan dana sebesar 100 juta, sedangkan dana yang diberikan pemerintah tidak sampai setengahnya, hanya 30 juta per tahun. Hal ini yang membuat pihak yayasan memikirkan banyak hal agar kebutuhan anak - anak panti dapat terpenuhi setiap harinya.

\section{Simpulan dan Saran}

\section{KESIMPULAN}

Yayasan widhya asih merupakan yayasan yang menampung anak - anak tidak memiliki orang tua dari yatim, piatu, maupun yatim piatu dan juga menampung anak dari keluarga yang kurang mampu ( dititipkan ). Penyusunan anggaran yang dilakukan oleh pihak yayasan menyesuaikan dengan kebutuhan dari anak - anak di yayasan itu sendiri. Walaupun sedikit dana yang diperoleh, namun pihak yayasan memiliki cara untuk mengolah sesuatu menjadi barang yang memiliki nilai jual dan dari hasil kreativitas anak - anak di dalam yayasan tersebut.

\section{SARAN}

Kami menyadari dalam penulisan mini riset ini masih terdapat kekurangan dan disusun dengan keterbatasan sumber, sehingga isinya mungkin belum menjurus ataupun masih merupakan pembahasan secara umum yang masih harus dikaji kembali kebenarannya.

\section{Daftar Pustaka}

Bastian. Indra, AKUNTANSI YAYASAN \& LEMBAGA PUBLIK,

Jakarta; PenerbitErlangga, 2007 
Jurnal IImiah Akuntansi dan Humanika, Vol. 7 No. 3, Desember 2017 ISSN: 2599-2651

Nordiawan, Deddi. 2009 Akuntansi Sektor Publik. Salemba 4, Jakarta Nainggolan, Pahala. 2005. Akuntansi Keuangan Yayasan dan Lembaga

Nirlaba Sejenis, Jakarta 